\title{
湯沢町におけるリゾート施設整備の実態に関する研究
}

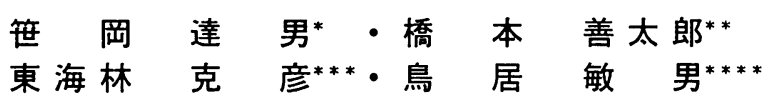

A Study on Resort Development in Yuzawa City

Tatsuo Sasaoka - Zentaro Hashimoto Katsuhiko ShoJI $\cdot$ Toshio Tori

\begin{abstract}
摘要 : 余暇時間の增大等を背景として、スキー場等のリゾート施設の整備による地域振興に対する期待が高まってい る一方, リゾート施設の整備による環境保全上の支障等が奬念されている。

本報では，適正なリソート施設整備の推進に資することを念頭に置きつつ，近年，リゾート施設が短期間に集中し て立地した湯沢町において, リゾート施設整備の実態として, リゾート施設整備の期間的・量的集中の実態及びかか る集中と基幹交通施設の整備との関係を調查するとともに, 地域振興効果等のメリット及び環境保全上の支障等のデ メリットを調查・分析した。
\end{abstract}

\section{1. 研究の背景及ひ目的}

余睱時間の增大や所得水準の向上等に伴い, 近年, 多 様な野外レクリエーション活動が盛んに行われるように なってきた。これに対応して, リゾート施設等の整備が 增加してきている。昭和62年 6 月には「総合保養地域整 備法」が施行され, 平成 5 年11月現在, 40地域の基本構 想が承認され，整備が進められているほか，多種多様な 主体により多種多様なリゾート施設整備が進められてい る。

これらのリゾート施設の整備は, 利用者側のニーズや 需要の増大に応じて進められてきているのみならず, 供 給側にとっては, リゾート施設整備の関係産業の発展, 過疎等に悩む農山村の振興等をも意図して, 行われてき ているものである。特に, 第 1 次産業以外の産業の立地 が困難な農山村地域は，一般に自然環境が豊かな地域で あることが多いため, リゾート施設の整備による地域振 興に対する期待は少なくないものがある。

一方, 不適切なリゾート施設の整備による自然生態系 や自然景観等の自然環境に与える悪影響等の発生も, 一 部の地域において指摘されている。特にゴルフ場やスキー 場等の大規模なリゾート施設の整備については, 条例や 要綱等により何らかの規制を行っている地方公共団体が 増えてきている。

また，リゾート施設整備の短期的・局所的な集中によ る諸問題の発生む指摘されている。本報の研究の対象地 域である新潟県湯沢町などでは, 比較的短期間の間に相 当数のリゾート施設の整備が集中し, 各種の環境問題の 発生, 地元住民の生活環境への悪影響, 土地利用の混乱,
上下水道・道路等の公共施設の整備の遅れ等の諸問題の 発生が指摘されている。

本報では，以上のようなリゾート施設整備に係る状況 を踏まえ，適正なリゾート施設整備の推進に資すること を念頭に置きつつ, 近年, リゾート施設が集中して立地 した新潟県湯沢町を対象地域として, (1)リゾート施設整 備の実態として, リゾート施設整備の期間的・量的集中 の実態及びかかる集中と基幹交通施設の整備との関係,

(2)ゾート施設整備による地域掁興効果等のメリット及 び環境保全上の支障等のデメリットの 2 点について主に 調査し, その結果を定量的に示しつつ整理することを目 的として調查を進めることとしたものである。なお，湯 沢町において, 近年, 集中して短期間に整備されてきた 主なリゾート施設は, スキー場とリゾートマンションで あることから, 本研究の対象とするリゾート施設は, こ の 2 種類とした。

\section{2.リソート施設整備の実笲等}

（1）湯沢町の概況

湯沢町は新潟県の最南端にあり, 西は長野県, 南は群 馬県に接しており, 東京から約 $170 \mathrm{~km}$ の距離帯に位置し ている。面積は, $357 \mathrm{~km}$ で, 9 割以上を山林が占め, 標 高 $1000 \mathrm{~m}$ 以上の山岳が 40 を数える山岳地帯である。人口 は, 9000 人前後で推移しており, 主要産業は温泉と冬季 のスキー等を中心とする観光関連産業である。

（2）リゾート施設整備の集中実態

湯沢町におけるリゾート施設整備の推移と現状を明ら

“環境庁自然保護局 **環境庁環境研修センター ***環境庁企画調整局 ****国土庁計画・調整局 
かにするため, 湯沢町資料及びスキー場事業者からの聞 き取り調査をもとに，スキ一場整備の推移（図一1）及 びマンション戸数の推移（図ー2）を作成した。これら の図によれば,ここ数年の短期間におけるリゾートマン ションと思われるマンションの戸数の増加（少なくとも 世帯数以上のマンション戸数は, リゾートマンション戸 数と見なすことができる。）及びスキ一場のゲレンデ面 積の拡大が読み取れる。なお，位置的には，主に湯沢温 泉地区と苗場地区に集中しており，スキー場とマンショ ンは隣接して整備されている傾向にある。

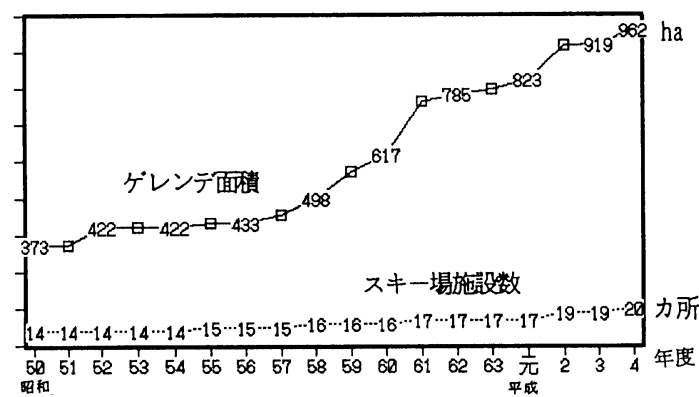

図一 1 スキー場整備の推移

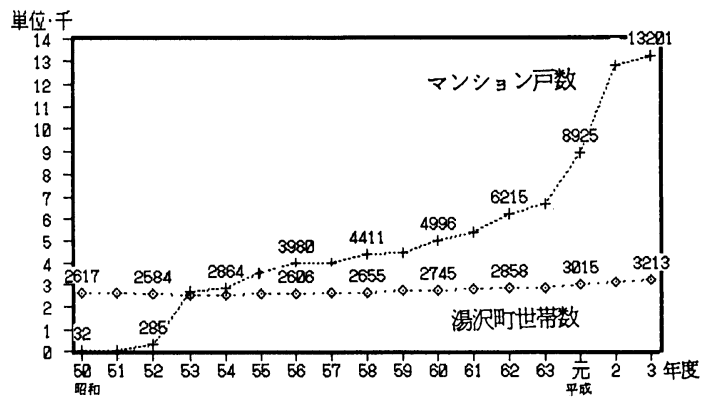

図ー 2 マンション戸数の推移

（3）スキ一場整備と基幹交通施設整備との関係

湯沢町において, スキ一場及びその関連施設としての リゾートマンションの開発が集中的に起きた原因として は，折からのスキーブーム，かね余りによるマンション 投資ブーム，高速道路・新幹線等の基幹交通施設の整備 による時間距離の短縮・輸送能力のアップ, 首都圈に近 い温泉のある古くからのスキ一場といった好立地条件, 特段の土地利用規制がなかった地域であったこと等の要 因があげられている。本報では，「高速道路・新幹線等 の基幹交通施設の整備による時間距離の短縮・輸送能力 のアップ」が, リゾート施設整備推進の引き金のひとつ となる報告を受け，スキー場整備と基幹交通施設整備と の関係を調査してみることとした。なお，東京との時間 距離は, 新幹線整備により 2 時間半から 1 時間15分に,
高速道路整備により 6 時間から 2 時間に短縮している。 図一 3 及び図ー 4 は, 鉄道及び高速道路による湯沢町 へのスキー利用者の入り込みの推移をみるために作成し たものであり，図一 3 は，日本道路公団資料をもとに作 成した関越自動車道湯沢料金所の乗用車の月別乗降車数, 図一 4 はJR東日本資料をもとに越後湯沢駅の月別乗降 客数である。なお, 月別に表示したのは, スキー客のみ に関するデータがないため, 冬季の積雪期のデータから スキー客と思われる数を推定するためである。図ー 3 及 び図ー 4 によれば， 1 年を通して年々利用車・者数は増 加している傾向にあるが，特にスキーシーズンである 1 月から 3 月の利用車・者数の伸びが著しい。スキー場の 増加とともに, 主にスキー利用を目的とした利用客と推 定される鉄道や高速道路による湯沢町への入り込み客が 増加してきているといえよう。

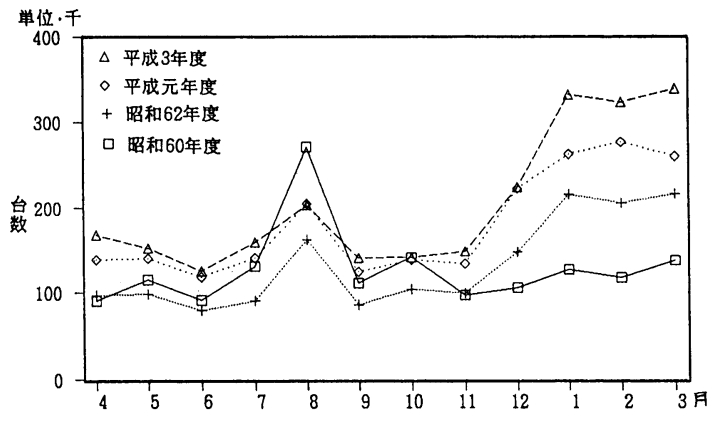

図一 3 関越自動車道湯沢料金所の月別乗降車台数

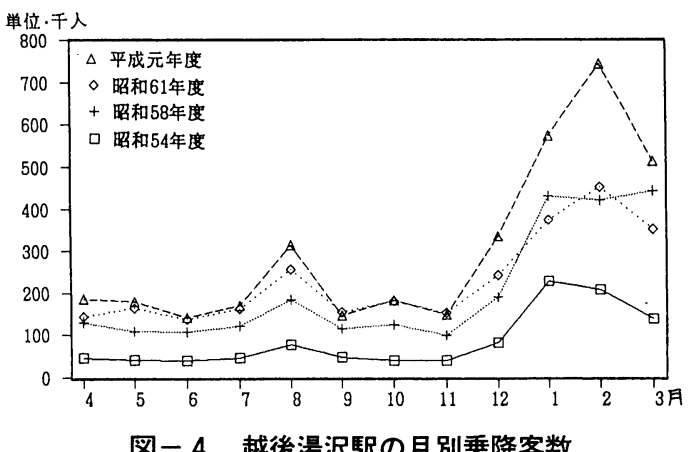

また，図ー 5 は，各スキー場事業者からの聞き取り調 查をもとに，スキー場整備と基幹交通施設の整備との関 係を調べたものである。定性的な評価になるが，図一 5 によれば, 基幹交通施設の整備の進捗にスキー場の新増 設が呼応するかのように整備されている傾向か読み取れ， 基幹交通施設の整備による時間距離の短縮・輸送能力の アップが，スキー場の集中的な整備に対して影響を持っ ていたらしいことがうかがえる。 

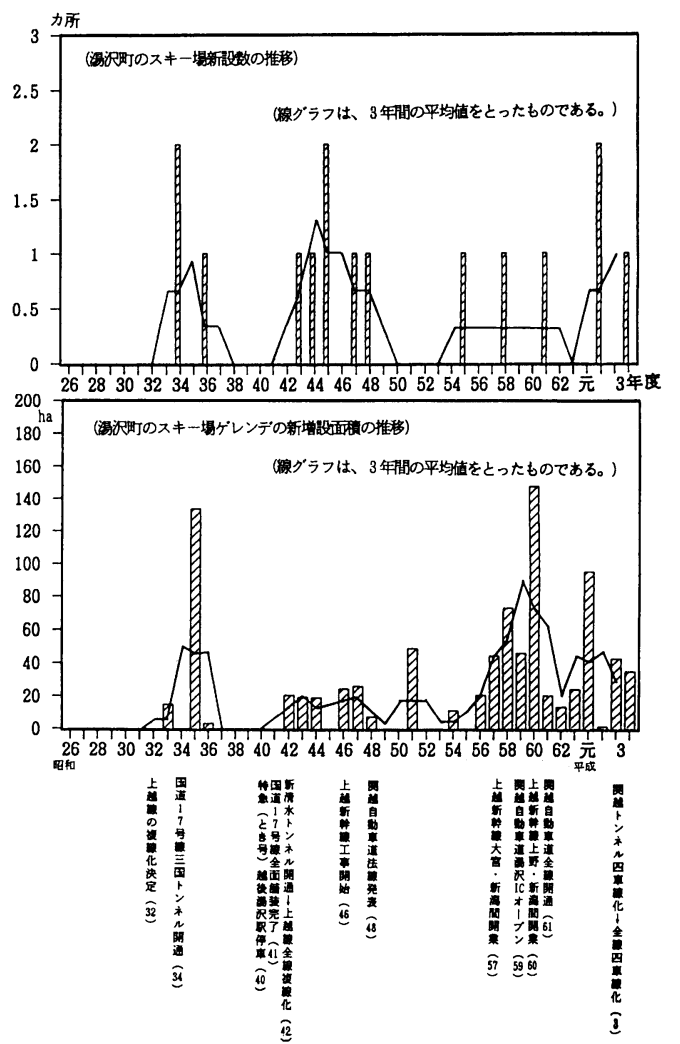

図ー5 スキー場整備よ基幹交通施設の整備よの関係

3. リソート施設整備のメリット及びデリット

リゾート施設の整備によるメリット，デメリットにつ いて, 報告書や町に対する聞き取り調查をもとに，その 概略をまとめたのが表一 1 である。

\section{表ー1 リゾート施設整備のメリットとデメリット}

\begin{tabular}{|c|c|}
\hline デメリット & メリット \\
\hline 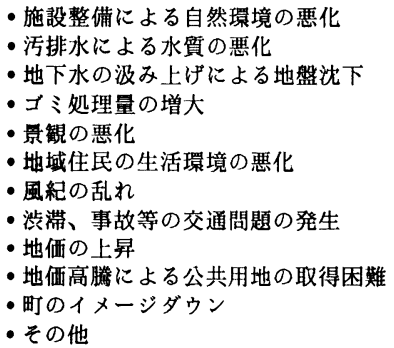 & 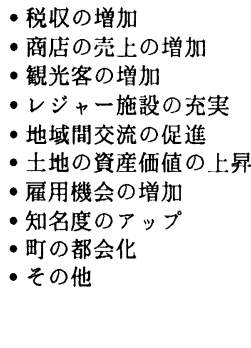 \\
\hline
\end{tabular}

なお, 湯沢町が町民に対して平成 3 年に実施したアン ケート調查によれば, リゾートマンション建設による悪 影響と好影響については，好影響よりも悪影響をあげる 人の方が多く, 図一6のような結果がでている。悪影響
としては, 交通渋滞, 自然破壊, 景観破壊, 公害問題の 順にあげられており，好影響としては，土地の資産価値 の上昇, 町の経済的な潤い, 㕍用機会の増加, 商店の売 上増加, 町の都会化の順にあげられているが, 「好影響 なし」としているものが最も上位となっている。
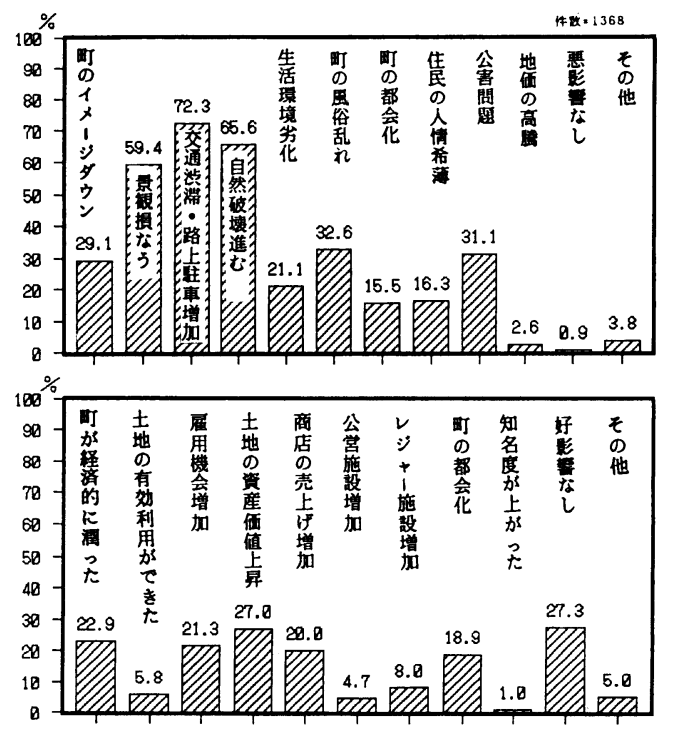

\section{図ー6 リソートマンション建設の悪影響と好影響}

以上の結果をもとに, リゾート施設整備による影響の 総合的評価を行うため，主なメリット及びデメリットに ついて個別に調へ，その内容や程度を調査してみた。そ の結果は, 次のとおりである。なお, 比較検討を行うこ とができるように, 同郡の隣接町である塩沢町及び六日 町のデー夕を載せている。塩沢町及び特に六日町は, 湯 沢町ほどではないもののスキー場等の整備がかなりなさ れてきている地域である。

\section{(1) メリット}

\section{(1)人口の増加}

人口の推移をみるため, 自治省「住民基本台帳」をも とに, 昭和 50 年度の人口に対する伸び率を求めてみたの

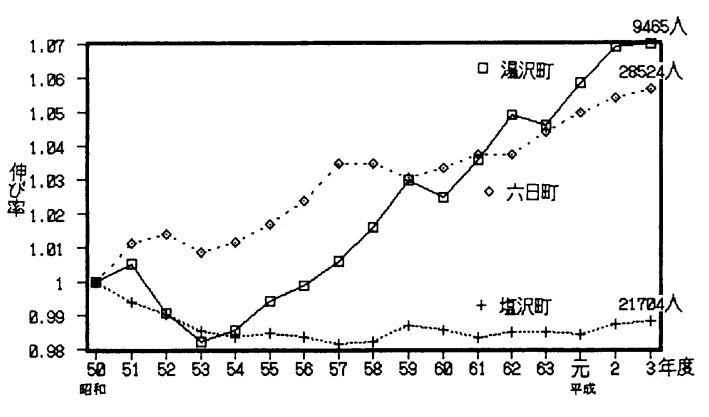

図-7 人口の推移 
が図ー7である。図ー 7 によれば，昭和50年代前半で低 迷が見られたものの人口は増加傾向にあり，近年の增加 率は 3 町の中で最む大きく，ここ10年で約 $7 \%$ 増えてい る。

\section{(2)雇用機会の増大}

産業別就業者数の推移をみるため, 通産省「事業所統 計調査」をもとに作成したのが表一 2 である。表一 2 に よれば，第 1 次及び第 2 次産業の就業者数は减少してい るが，第 3 次産業は増加しており，特にサービス業の増 加が著しい。なお，全体としても，新幹線や高速道路の 建設工事で一時的に建設業就業者数が多くなっていた昭 和50年度を除いて考えると，増加傾向にあるといえる。

\section{表-2 産業別就業者数の推移}

\begin{tabular}{|c|c|c|c|c|c|}
\hline & & & & & （単位 \\
\hline & & 50 & 55 & 60 & 2 年度 \\
\hline$\vec{~} \vec{\alpha}$ & 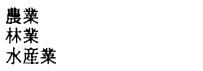 & $\begin{array}{lll}7 & 1 & 4 \\
& 9 & 4 \\
& & \\
& \end{array}$ & $\begin{array}{rrr}40 & 6 \\
8 & 4 \\
& & 1\end{array}$ & $\begin{array}{rrr}41 & 8 \\
7 & 0 \\
& & 1\end{array}$ & $\begin{array}{r}253(4.3 \%) \\
48(0.8 \%) \\
\quad 2(0 \%)\end{array}$ \\
\hline 㐸 & $\begin{array}{l}\text { 鉱菓 } \\
\text { 建设䉾 } \\
\text { 叫造菜 }\end{array}$ & 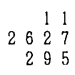 & $\begin{array}{r}\quad 14 \\
1476 \\
279\end{array}$ & $\begin{array}{lll} & & 4 \\
8 & 9 & 3 \\
3 & 1 & 8\end{array}$ & 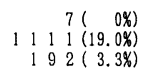 \\
\hline 三 & 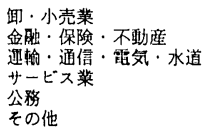 & $\begin{array}{rrr}7 & 8 & 4 \\
4 & 1 \\
4 & 75 \\
1 & 52 & 5 \\
1 & 4 & 5 \\
& 1 & 0\end{array}$ & $\begin{array}{rrr}8 & 4 & 1 \\
& 5 & 2 \\
5 & 1 & 5 \\
15 & 0 & 8 \\
1 & 5 & 0\end{array}$ & $\begin{array}{r}919 \\
886 \\
627 \\
1798 \\
167 \\
16 \\
\end{array}$ & 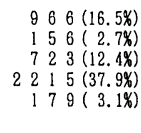 \\
\hline & 合㖕 & 6721 & 5386 & $\begin{array}{llll}5 & 3 & 0 & 3\end{array}$ & $5843(100 \%)$ \\
\hline
\end{tabular}

(3)町財政の向上

町財政の推移をみるため, 自治省「市町村別決算状況 調べ」をとに作成した財政力指数の推移が図ー8であ る。なお，財政力指数とは，基準財政支出額の基準財政 需要額に対する比を 3 年度分平均したもので, 地方公共 団体の財政上の能力を示す指標である。図一8によれば, 財政力指数は他の 2 町に比べてかなりの増加傾向を示し ている。

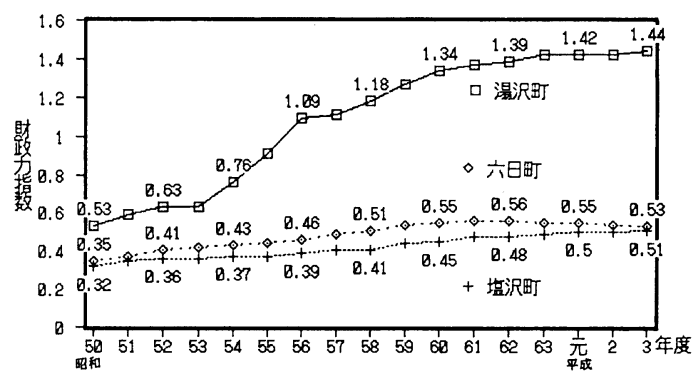

図-8 財政力指数の推移
商業販売額の推移をみるため, 通産省「事業所統計調 査」をもとに, 昭和 50 年度の小売及び卸売業の販売額に 対する伸び率を求めてみたのが図ー 9 である。図ー 9 に よれば，小売り及び卸売業の年間販売額は，3町とも増 加傾向にあるが，湯沢町の伸び率が最も大きい結果がで ている。

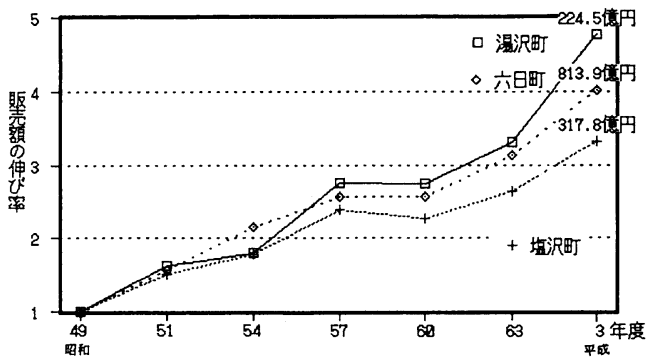

図-9 小売り及ひ卸売業の年間販売額の推移

(2) デメリット

(1)緑地の減少

緑地の減少実態を調べるため，湯沢町「固定資産税概 要調書」をむとに作成した地目別面積の推移が表ー 3 で ある。 5 年ごとに再測量等があり, 合計面積が異なるた め単純に比較はできないが，少なくとも宅地の増加傾向 は読み取れる。その主な転換源であり，緑地面積のほと

\section{表ー3 地目別面積の推移}

\begin{tabular}{|c|c|c|c|c|c|c|}
\hline & 田畑 & 山林 & 原野 & 宅地 & その他 & 計 ha \\
\hline 昭和 57 年度 & $\begin{array}{r}444 \\
(1 \%)\end{array}$ & $\begin{array}{l}32507 \\
(92 \%)\end{array}$ & $\begin{array}{l}1019 \\
(3 \%)\end{array}$ & $\begin{array}{r}127 \\
(0 \%)\end{array}$ & $\begin{array}{l}1414 \\
(4 \%)\end{array}$ & $\begin{array}{c}35511 \\
(100 \%)\end{array}$ \\
\hline 59 年度 & $\begin{array}{r}421 \\
(1 \%)\end{array}$ & $\begin{array}{l}32629 \\
(92 \%)\end{array}$ & $\begin{array}{l}1004 \\
(3 \%)\end{array}$ & $\begin{array}{l}134 \\
(0 \%)\end{array}$ & $\begin{array}{l}1308 \\
(4 \%)\end{array}$ & $\begin{array}{r}35496 \\
(100 \%)\end{array}$ \\
\hline 61 年度 & $\begin{array}{r}408 \\
(1 \%)\end{array}$ & $\begin{array}{l}32615 \\
(92 \%)\end{array}$ & $\begin{array}{r}984 \\
(3 \%)\end{array}$ & $\begin{array}{r}143 \\
(0 \%)\end{array}$ & $\begin{array}{l}1342 \\
(4 \%)\end{array}$ & $\begin{array}{r}35496 \\
(100 \%)\end{array}$ \\
\hline 63 年度 & $\begin{array}{r}399 \\
(1 \%)\end{array}$ & $\begin{array}{l}32553 \\
(92 \%)\end{array}$ & $\begin{array}{r}879 \\
(3 \%)\end{array}$ & $\begin{array}{l}152 \\
(0 \%)\end{array}$ & $\begin{array}{l}1266 \\
(4 \%)\end{array}$ & $\begin{array}{r}35496 \\
(100 \%)\end{array}$ \\
\hline 平成 2 年度 & $\begin{array}{r}377 \\
(1 \%)\end{array}$ & $\begin{array}{l}32821 \\
(92 \%)\end{array}$ & $\begin{array}{r}904 \\
(3 \%)\end{array}$ & $\begin{array}{r}162 \\
(0 \%)\end{array}$ & $\begin{array}{l}1436 \\
(4 \%)\end{array}$ & $\begin{array}{r}35700 \\
(100 \%)\end{array}$ \\
\hline
\end{tabular}

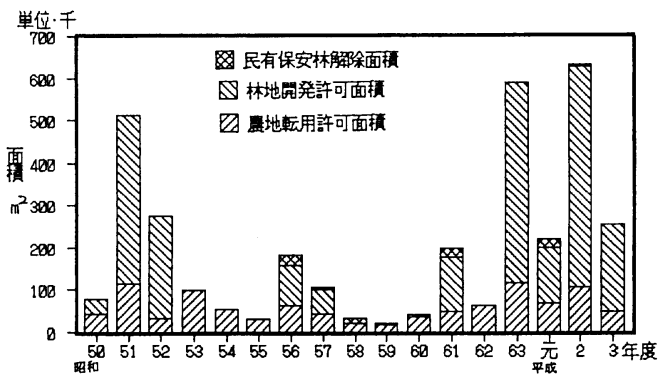

図-10 農地及ひ森林の減少面積（単年度）の推移 
んどを占める農地や森林の面積の減少面積を単年度ごと に整理してみたのが図ー10である。データは，新潟県資 料をるとに求めた, 農地転用許可面積, 林地開発許可面 積及び民有保安林解除面積の和であり，おおよそ農地及 び森林の減少面積に相当するとみなすことができるすの である。図ー10によれば，近年，農地及び森林の減少面 積は増加傾向にある。

\section{(2)水質の悪化}

水質の悪化状況をみるため，環境庁資料をもとに作成 したのが図ー11である。測定点は，湯沢町市街地の約 18 $\mathrm{km}$ 下流に位置する環境基準点（魚野川下流柳生橋）であ る。図ー11によれば，BODの $75 \%$ 値は昭和 57 年に当該 地域の環境基準をわずかにこえているものの，ほぼ横ば い状態であり，水質の悪化は認められない。一方，SS の平均値は年变動が激しく, 顕著な变化傾向は見られな い。なお, 当該地域一帯においては, 下水道の整備が進 められているところである。

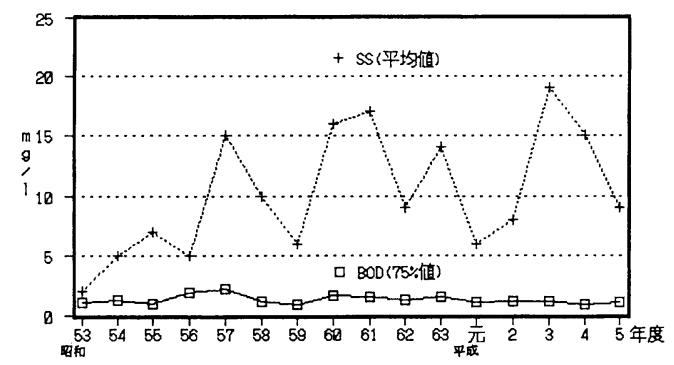

図一11 水質の推移

(3)町財政の費用負担の増加

町財政の費用負担の増加をみるために，湯沢町資料を もとに作成したのが図ー12である。図ー12によれば，近

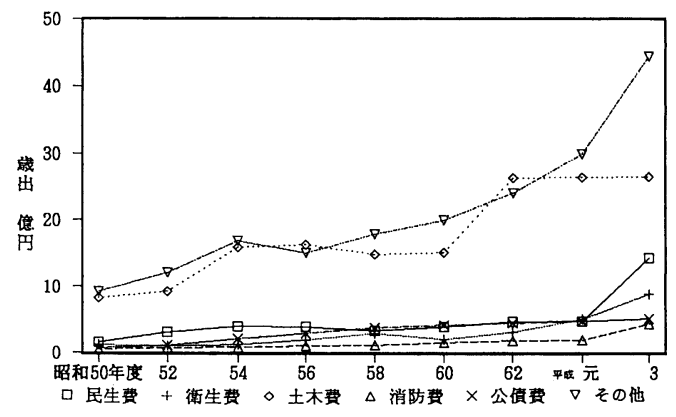

図-12 湯沢町の歲出の推移

年，增加傾向を示している費目があるが，町の話による と急激な伸びは老朽化した公民館や消防署の整備があっ
たためであり，緩やかな伸びは自然増と考えた方が適当 ということであった。また，リゾート利用客の急増に伴っ て, 上下水道や道路整備のための費用負担が増加したと いう実感も，あまり感じられないとのことであった。

\section{(4)景観の悪化}

景観の悪化については，スキー場やマンション整備に よる自然景観の悪化と, 無秩序な形態・意匠による都市 景観の悪化の 2 つの問題がある。自然地域における多数 のスキー場やマンション整備により，自然景観が損なわ れたことは明らかであろうが，都市贯観の悪化について は, 定量的に評価し難い側面がある。しかし, 平成元年 4 月現在, 11階建て以上のマンションが15棟整備され, その色彩もブルー系, ピンク系, イエロー系とまちまち である実態からして，功る都市景観の変化を好ましい と評価する人は少ないものであろうと思われる。

（3）その他

(1)地価上昇

地価上昇については，土地の取得が困難になるという 点では悪影響とも，資産価值の上昇という点では好影響 ともいうことができる。図一13は，新潟県「地価調査」 をもとに，地価の推移を調べたものである。なお，調査 地点が变動しているため, 通しで地価の推移をみること はできなかった。いずれす調査地点は，住居地域内に位 置しているものである。図-13によれば，塩沢町や六日 町の調查地点の地価に比べて, 湯沢町の調査地点の地価 は高くなってきている傾向を示している。

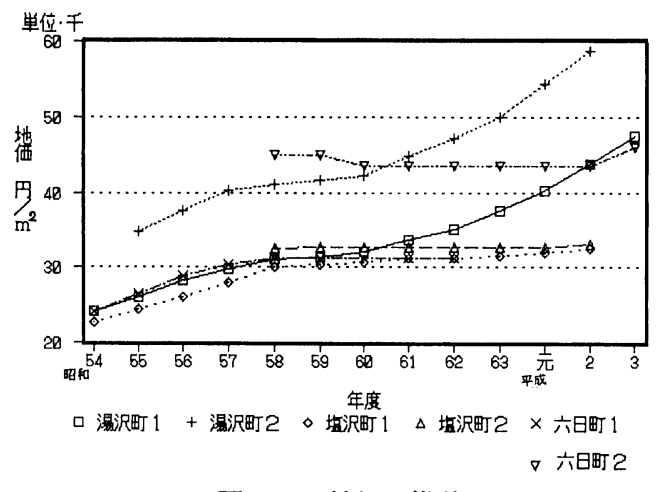

図-13 地価の推移

以上，リゾート施設の整備による主なメリット，デメ リットについて，可能な限り実証的に個別に分析してみ た。その結果，一般的に言われていることだが，リゾー 卜施設の整備は, 環境問題の発生のデメリットがある一 方, 地域振興効果のメリットも大であることが定量的に 明らかになった。リゾート施設の整備については，えて 
して目的や立場の違いにより，メリットデメリットの 一側面ばかりが強調されることが多いが，今後のリゾー 卜施設の整備に当たっては，両者の十分な調整を図り， 計画的・総合的な観点から対応していく必要があると考 えられる。

\section{4. まとめ}

本報では，適正なリゾート施設整備の推進に資するこ とを念頭に置きつつ, 近年, リゾート施設が集中して立 地した湯沢町において, リゾート施設整備の実態を調查 し, 地域掁興効果等のメリット及び環境保全上の支障等 のデメリットを整理・分析した。本研究を通じて得られ た結果は, 次のとおりである。

(1)リゾート施設が短期間で多数集中して立地しているこ とが定量的に明らかになった。

(2スキー場の整備と，基幹交通施設の整備との関係を調 査した。その結果, 基幹交通施設の整備による時間距離 の短縮・輸送能力のアップの, スキー場の集中的な整備 に対する影響がうかがえた。

(3)ゾート施設の整備によるメリット，デメリットは色々 であるが，その実態について個別に分析した。その結果，
リゾート施設の整備は, 環境問題の発生のデメリットが ある一方, 地域振興効果のメリットも大であることが定 量的に明らかになった。

最後になるが，こ協力を頂いた環境庁自然保護局，国 土庁計画・調整局, 新潟県土地利用調整課及び湯沢町企 画課に謝意を表する次第である。

\section{参考文献}

1 ) 国土庁計画 ・調整局 (1993) : 第四次全国総合開発 計画総合的点検中間報告: 大藏省印刷局

2 ) 環境庁 (1989): 自然・ふれあい新時代 : 第一法規

3 ) 環境庁 (1993): 平成 4 年度リゾート開発環境保全 手法調查報告毒 : 環境庁

4 ）新潟日報社（1989）：東京都湯沢町：潮出版社

5 ) 湯沢町 (1992): 町勢要覧 : 湯沢町

6 ) 月刊観光編集部 (1986): 高速交通体系の变化の中 でー越後湯沢レポートー：月刊観光 5 月号

7 ）（社）ソフト化経済センター（1989）：リゾート開 発の現状PARTIII：（社）ソフト化経済センター

8 ) 湯沢町 (1991)：湯沢町住民アンケート調查分析結 果報告書 : 湯沢町

Summary : Resort development is expected to be a locomotion of regional economic development, but on the other hand, it would cause environmental pollution. Resort facilities, mainly ski ground, have been highly concentrated in a very short time of period in Yuzawa City. Then, through the analysis of trank traffic facilities such as express way, shinkansen, etc, its influence onto construction of ski ground is clarified. And the problems in the development is looked into in detail, in order to find out merits on regional economy and demerits on environment there. 